AL IBTIDA: JURNAL PENDIDIKAN GURU MI (2021) Vol 8 (2) : 178-190

DOI: http://dx.doi.org/10.24235/al.ibtida.snj.v8i2.8794

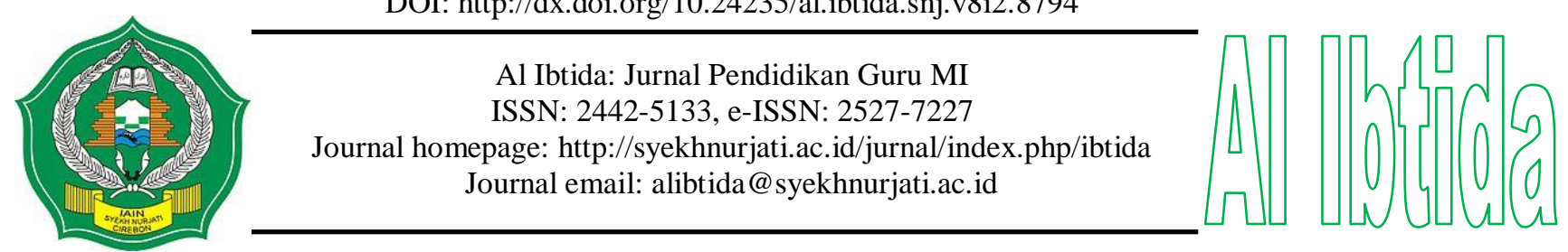

\title{
Mapping Higher Order Thinking Skills of Prospective Primary School Teachers in Facing Society 5.0
}

\author{
Dini Ramadhani* \\ *Primary School Teacher Education Study Program, Training and Education Faculty, \\ Universitas Samudra, Indonesia. \\ Email: diniramadhani@unsam.ac.id \\ Ary Kiswanto Kenedi** \\ **Primary School Teacher Education Study Program, Training and Education Faculty, \\ Universitas Samudra, Indonesia. \\ Email: arykenedi@unsam.ac.id \\ Yullys Helsa**** \\ ***Primary School Teacher Education Study Program, Education Faculty, \\ Universitas Negeri Padang, Indonesia. \\ Email: yullys@fip.unp.ac.id \\ Ciptro Handrianto**** \\ **** Pedagogy Departement, Faculty of Human Development, \\ Universiti Pendidikan Sultan Idris, Malaysia. \\ E-mail: handriantociptro@gmail.com \\ Muhammad Rizki Wardana***** \\ *****Primary School Teacher Education Study Program, Training and Education Faculty, \\ Universitas Samudra, Indonesia. \\ E-mail: rizkiwardana1308@gmail.com
}

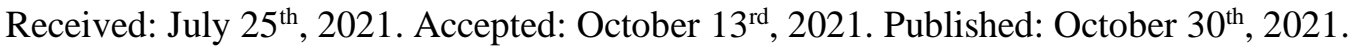

\begin{abstract}
The need to develop higher order thinking skills (HOTS) for prospective primary school teachers in facing society 5.0 has been motivating this research. This development process requires valid data regarding the HOTS description of prospective primary school teachers. The research is aimed to determine the HOTS ability of prospective primary school teachers in facing society 5.0. This is a qualitative descriptive study involving 125 senior students in the department of primary school teacher education. The data collection instrument utilized the validated mathematical HOTS test questions. The resulting score is then converted to an ideal score and mapped. The average score attained by prospective primary school teacher students was 57.01, according to the findings. This score indicates that prospective teachers' HOTS ability is in the fairly good category. The findings of this study can be used to improve HOTS for future teachers.
\end{abstract}

Keywords: HOTS, prospective primary school teacher, mathematics. 


\begin{abstract}
Abstrak
Penelitian ini dilatarbelakangi pentingnya pengembangan HOTS calon guru sekolah dasar (SD) dalam menghadapi era society 5.0. Proses pengembangan ini diperlukan data valid mengenai gambaran HOTS calon guru SD. Tujuan penelitian ini adalah untuk menggambarkan kemampuan HOTS calon guru SD pada pembelajaran matematika dalam menghadapi era society 5.0. Penelitian ini merupakan penelitian deskriptif kualitatitif dengan melibatkan sebanyak 125 mahasiwa akhir di jurusan pendidikan guru sekolah dasar. Instrumen pengumpulan data menggunakan soal test HOTS matematis yang telah divalidasi. Skor yang didapatkan kemudian di tranformasi ke skor ideal dan kemudian dipetakan. Hasil penelitian menunjukkan bahwa skor rata-rata yang diperoleh oleh mahasiswa calon guru SD adalah 57,01. Skor ini membuktikan bahwa kemampuan HOTS mahasiswa calon guru berada pada kategori cukup baik. Implikasi penelitian ini dapat dijadikan landasan dalam pengembangan HOTS calon guru ke depan.
\end{abstract}

Kata kunci: HOTS, calon guru SD, matematika.

\title{
INTRODUCTION
}

The development of global trends represents an era called society 5.0 (Elyasni, Kenedi \& Sayer, 2019; Helsa \& Kenedi, 2019). This era presents various innovations in life processes as a result of the development of industry 4.0. Society 5.0 has a connection and correlation between real space and virtual space. Society 5.0 is characterized by the existence of big data processes, machine learning, robotics, and the internet of things, which are the result of industry 4.0 (Evtodieva et al, 2020; Wan et al, 2020; Winkelhaus \& Grosse, 2020). So, society 5.0 is an era that combines the life processes of real space with virtual space in solving social problems.

The era of society 5.0 must be faced wisely. Education development is one of the ways to deal with society 5.0 (Fuji, Guo, \& Kamoshida, 2018; Saputro et al, 2020). Education has an important role in the era of society 5.0 (Fachrunnisa, Adhiatma \& Tjahjono, 2020; Polat \& Erkollar, 2020). Education is an essential factor in improving human quality (Carayannis, Draper, \& Haneja, 2020). Therefore, various efforts are needed to improve the quality of the community. One indicator of quality development is higher-order thinking skills or known as HOTS.

HOTS is one of the critical components that every individual in industry 4.0 should acquire. HOTS is a higher-order thinking skill that demands people to develop their thoughts in a specific way, resulting in a new understanding and application (Ahmad et al, 2019). Developing these ideas requires the ability to think critically and creatively to solve the encountered problems (Ahmad et al, 2019). HOTS is a way of thinking that goes beyond memorizing and presenting facts (Garcia, 2015). HOTS is also a cognitive process occurring 
in short-term memory (Lu, Pang, \& Shadiev, 2021). Bloom and Anderson divide HOTS into the ability to analyze, assess and create (Dubas \& Tuledo, 2016). Analyzing and assessing are part of the critical thinking process while creating is a creative thinking skill. As a result, HOTS is a cognitive process that allows people to think more critically and creatively when solving problems in everyday life.

HOTS needs to be owned by every individual. HOTS can be developed in the learning process, including the mathematics learning process in universities. Mathematics is one of the courses that every college student must take (Tanujaya, Mumu, \& Margono, 2017). Not only making the individual solve problems easily, but mathematics is also a forum for developing individual HOTS (Pratama \& Retnawati, 2018). Individuals must think critically and creatively while examining problems and solving the problems in learning mathematics (Apino \& Retnawati, 2018; Arifuddin, 2019). This demonstrates that learning mathematics is in line with the objectives of HOTS.

Students are not the only ones who must understand HOTS, but the teachers also should be proficient in HOTS. Teachers are responsible for developing HOTS for their students and must ensure that the teachers themselves, particularly primary school teachers, have HOTS. Teachers in primary schools are responsible for giving fundamental concepts and skills to their students (Habók \& Nagy, 2016). Teachers must ensure that students understand HOTS since primary school (Arifuddin, 2019). So, they can apply it in their daily lives and continue to develop it in higher education. As a result, a primary school teacher must be capable of mastering HOTS.

A primary school teacher must come from the department of primary school teacher education because they will be trained to become future professional primary school teachers. In the primary school teacher education program, students also need to develop this HOTS ability. Therefore, it is necessary to develop HOTS of primary school teacher education students as prospective primary school teachers.

However, before developing HOTS, concrete data regarding the HOTS mapping of prospective primary school teachers are needed. This mapping aims to determine valid, up-todate, and accountable data regarding the HOTS description of primary school teacher education students. Somatanaya and Nugraha (2018) researched HOTS mapping on junior high school students in Tasikmalaya City. The results showed that students with moderate HOTS levels could analyze arguments and identify main ideas, while students with low HOTS levels could not analyze arguments and identify main ideas. Incikabi et al. (2013) did research in Turkey in 2013 that supports this study. The research was undertaken to learn 
about future mathematics teachers' critical thinking and logical thinking skills, and it was discovered that prospective mathematics teachers had low critical thinking and logical thinking skills based on the findings. This research is also reinforced by a study conducted by Allamnakhrah (2013) in Saudi Arabia on the relevance of implementing a learning process that drives the improvement of prospective teachers' critical thinking skills at universities. According to the findings, the requirement for learning that can increase teachers' critical thinking skills is related to the teachers' low critical thinking skills. Furthermore, this research is supported by Abdullah et al. (2016) in Malaysia, who researched to determine the level of understanding and practice of mathematics teachers in implementing HOTS-based learning, with the conclusion that the HOTS' learning process was not implemented to its full potential due to a lack of knowledge and experiences. Then, Shukla and Dungsungnoen (2016) researched in Thailand to investigate the level of student perceptions of HOTS and teacher learning strategies related to HOTS, with the findings indicating that students' HOTS ability is in the medium category. This study differs from the previous ones in that it aims to determine the HOTS abilities of prospective elementary school teachers, with the HOTS focusing on characteristics of critical thinking skills and creative thinking skills.

In sum, this research is critical because a primary school teacher must have the HOTS ability to develop the HOTS of primary school students. However, it is necessary to understand the proper HOTS mapping for a prospective primary school teacher to find the best solution for future HOTS development. Therefore, the purpose of this study was to find out the mapping of HOTS for prospective primary school teachers.

\section{METHODS}

The design of this research is qualitative descriptive research. The research flow begins with the collection of data through a test. The test results are then reduced according to indicators of high-order thinking skills. After that, the data are presented to conclude. The sample of this research consisted of 125 final-year students (102 female students and 23 male students), with the assumption that these students had finished all mathematics-related subjects in class. The instrument of data collection is essay questions that had been validated by two mathematicians who have expertise in HOTS and get use approval. Thirty questions in total were validated, but only 9 of them were chosen as indicators of mathematical HOTS ability. The dimensions of critical thinking skills and the dimensions of creative thinking skills are the two dimensions that make up the indicators of mathematical HOTS ability. The ability to apply concepts, principles, predict impacts and solve issues are indicators of critical 
thinking skills, whereas the ability to make decisions, work within limitations of competence, try new things, think divergently, and think imaginatively are indicators of creative thinking skills. The score obtained is then converted to an ideal score of 100 . The score is converted into a HOTS scoring category based on the following table:

Table 1. Criteria for HOTS Mastery Category

\begin{tabular}{ll}
\hline Mastery Interval & Mastery Level Category \\
\hline $85 \leq X \leq 100$ & Best \\
$70 \leq X<85$ & Good \\
$50 \leq X<70$ & Fairly good \\
$0 \leq X<50$ & Poor \\
\hline
\end{tabular}

(Based on the International Center for the Assessment of Higher Order Thinking)

The research begins by analyzing the HOTS indicators and developing research instruments. Then validation is carried out to determine face validity and content validity. The HOTS test is given to prospective primary school teachers after the research instrument is declared valid and feasible for use in measuring HOTS. The test results are analyzed descriptively and inferentially to present the HOTS of prospective primary school teachers.

\section{RESULTS AND DISCUSSION}

HOTS questions were given to prospective elementary school teachers as part of the data collection procedure. Each sample must take the test individually. The questions given represent each of the HOTS indicators. Each question has a maximum score of 3 and a minimum score of 0 . The maximum number that prospective primary school teacher students can obtain is 21 .

The following are examples of questions and answers done by prospective teachers:

There are nine numbers from 1 to 9. The command is how to store the numbers in a 9-square grid (as in the picture) so that the sum of each number in the vertical, horizontal, or diagonal directions is the same?

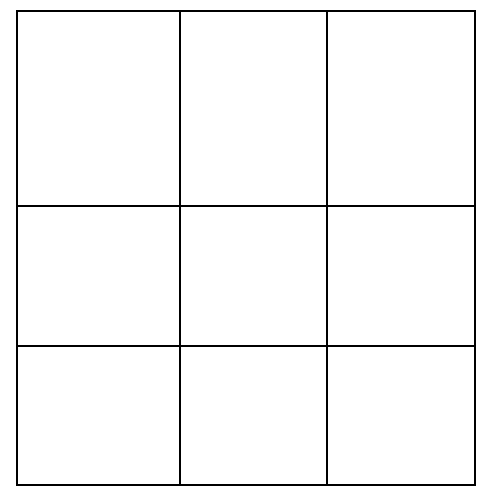

This question is a form of creative thinking ability question with imaginative thinking indicators. In this question, prospective teachers must understand the problems that occur. 
Prospective teachers must be able to find a pattern of squares and follow the rules of the question. In finding this square pattern, creative abilities are needed to imagine all possible answers that could be given. The following are some samples of responses and scores for these questions.

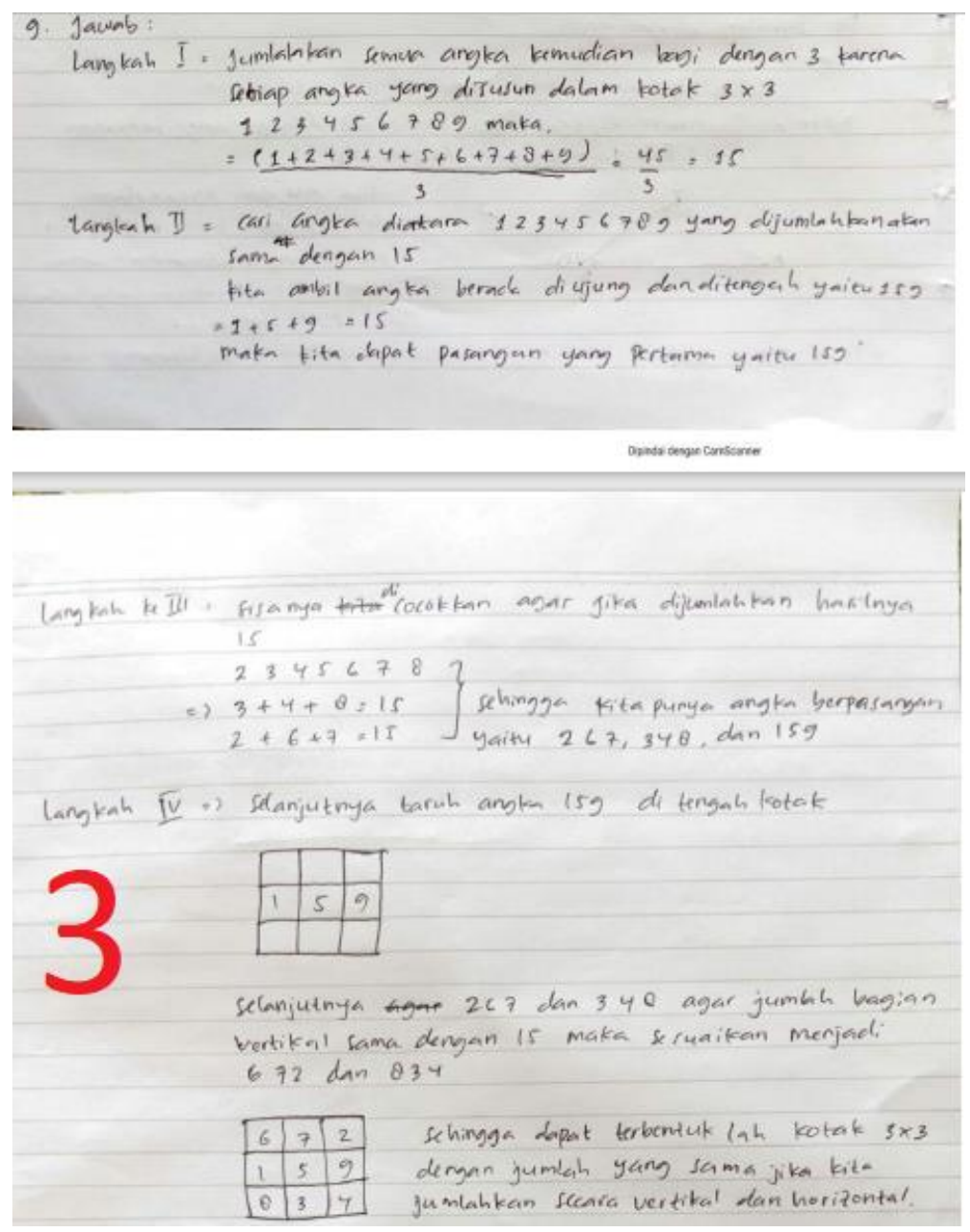

Figure 1. Answers of prospective primary school teachers

All of the answers from prospective primary school teachers were checked and assessed. The score is converted to a 100-point scale. Furthermore, these scores are divided into three categories based on the HOTS indicators: high, medium, and low, as shown in the table below:

Table 2. HOTS ability scores obtained

\begin{tabular}{lllllll}
\hline $\begin{array}{l}\text { Type of } \\
\text { HOTS }\end{array}$ & Indicator & $\begin{array}{l}\text { Category } \\
\text { Level }\end{array}$ & $\begin{array}{l}\text { Average } \\
\text { Raw } \\
\text { Score }\end{array}$ & $\begin{array}{l}\text { Average } \\
\text { score (scale } \\
\text { of 100) }\end{array}$ & $\begin{array}{l}\text { Average } \\
\text { total } \\
\text { score }\end{array}$ & $\begin{array}{l}\text { Mastery } \\
\text { Category }\end{array}$ \\
\hline $\begin{array}{l}\text { Critical } \\
\text { Thinking }\end{array}$ & Using & High & 14,44 & 66,76 & & \\
Ability & Using & Medium & 12,26 & 57,34 & 57,24 & Fairly good \\
& Low & 10,26 & 47,63 & & \\
\hline
\end{tabular}




\begin{tabular}{|c|c|c|c|c|c|c|}
\hline & \multirow[t]{2}{*}{ principles } & Medium & 13,78 & 61,98 & & \multirow{5}{*}{ Fairly good } \\
\hline & & Low & 9,34 & 42,86 & & \\
\hline & \multirow{3}{*}{$\begin{array}{l}\text { Predicting } \\
\text { impacts }\end{array}$} & High & 10,91 & 52,18 & \multirow{3}{*}{52,29} & \\
\hline & & Medium & 11,98 & 57,09 & & \\
\hline & & Low & 10,12 & 47,62 & & \\
\hline & \multirow{3}{*}{$\begin{array}{l}\text { Solving } \\
\text { problems }\end{array}$} & High & 15,34 & 71,56 & \multirow{3}{*}{63,57} & \multirow{3}{*}{ Fairly good } \\
\hline & & Medium & 16,12 & 76,29 & & \\
\hline & & Low & 9,34 & 42,86 & & \\
\hline \multirow{15}{*}{$\begin{array}{l}\text { Creative } \\
\text { Thinking } \\
\text { Ability }\end{array}$} & \multirow{3}{*}{$\begin{array}{l}\text { Making } \\
\text { decisions }\end{array}$} & High & 15,12 & 71,43 & \multirow{3}{*}{61,90} & \multirow{3}{*}{ Fairly good } \\
\hline & & Medium & 12,1 & 57,24 & & \\
\hline & & Low & 9,63 & 57,04 & & \\
\hline & \multirow{3}{*}{$\begin{array}{l}\text { Working } \\
\text { within the } \\
\text { limits of } \\
\text { competency }\end{array}$} & High & 14,34 & 66,34 & \multirow{3}{*}{63,28} & \multirow{3}{*}{ Fairly good } \\
\hline & & Medium & 11,12 & 52,18 & & \\
\hline & & Low & 15,21 & 71,34 & & \\
\hline & \multirow{3}{*}{$\begin{array}{l}\text { Trying new } \\
\text { things }\end{array}$} & High & 11,19 & 52,18 & \multirow{3}{*}{42,87} & \multirow{3}{*}{ Poor } \\
\hline & & Medium & 8,21 & 38,29 & & \\
\hline & & Low & 8,61 & 38,15 & & \\
\hline & \multirow{3}{*}{$\begin{array}{l}\text { Thinking } \\
\text { divergently }\end{array}$} & High & 15,16 & 71,54 & \multirow{3}{*}{67,11} & \multirow{3}{*}{ Fairly good } \\
\hline & & Medium & 13,21 & 62,90 & & \\
\hline & & Low & 14,12 & 66,90 & & \\
\hline & \multirow{3}{*}{$\begin{array}{l}\text { Thinking } \\
\text { imaginatively }\end{array}$} & High & 14,44 & 66,67 & \multirow{3}{*}{44,44} & \multirow{3}{*}{ Poor } \\
\hline & & Medium & 9,34 & 42,87 & & \\
\hline & & Low & 5,12 & 23,80 & & \\
\hline \multicolumn{5}{|c|}{ Average } & 57,01 & $\begin{array}{l}\text { Fairly } \\
\text { good }\end{array}$ \\
\hline
\end{tabular}

From Table 2, the average HOTS of prospective primary school teachers is in the fairly good category with a score of 57,01 . However, creative thinking ability with indicators of trying new things and thinking imaginatively is in the poor category. The results of the HOTS ability can be seen in the following diagram to simplify the presentation. 


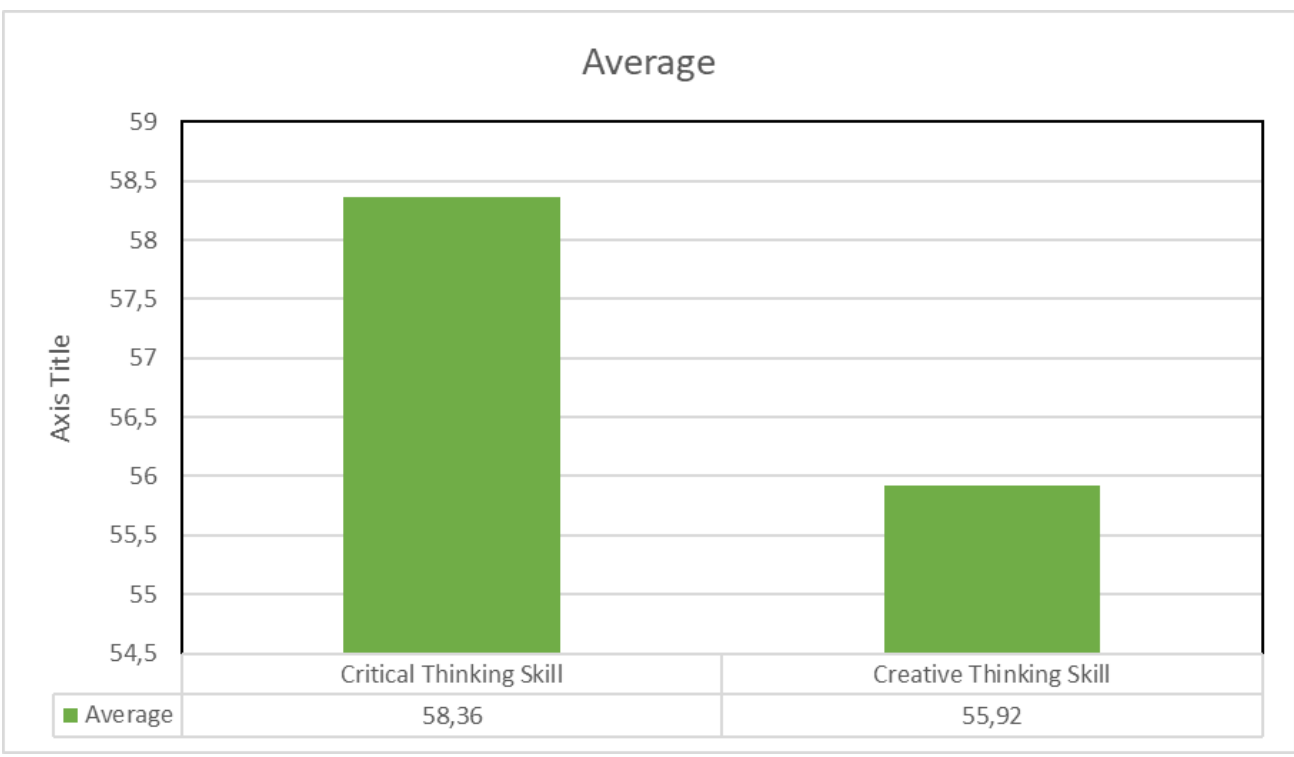

Figure 1. Diagram of HOTS result

Figure 1 shows that the average critical thinking skill of prospective teachers is 58.36, which is in the "fairly good" category, while the average creative thinking skill is 55.92, which is in the "fairly good" category. However, as can be seen from the diagram, the creative thinking skill is lower than the critical thinking skill, due to the poor category of trying new things and thinking imaginatively.

The findings are almost identical to those of Syafri et al (2017), who found that PSTE students' HOTS is below average. The study, however, did not show HOTS ability indicators. Therefore, the ability of PSTE students based on HOTS indicators was not obvious. Meanwhile, this study describes the achievement of primary school teacher candidates from each indicator consisting of critical thinking and creative thinking aspects. In the critical thinking aspect, the average achievement of primary school teacher candidates is in the fairly good category. Meanwhile, in the creative thinking aspect, indicators of trying new things and imaginative thinking are in the poor category. These results prove that the HOTS ability of primary school teacher candidates in facing society 5.0 is fairly good.

HOTS ability is the ability to carry out the process of solving problems critically and creatively. In this study, critical thinking ability consists of the ability to use concepts, use principles, predict impacts, and solve problems. In the indicator of using concepts, prospective primary school teachers are in the fairly good category. This category means that prospective primary school teachers have begun to use mathematical concepts and connect them with other concepts as a whole. In the indicators of using principles, they are in the fairly good category. This result means that prospective primary school teachers have begun to use mathematical principles in solving mathematical problems. Prospective primary school 
teachers can use mathematical principles critically in solving mathematical problems. In the predicting impact indicator, prospective primary school teachers are in the fairly good category. This result means that prospective primary school teachers have begun to predict the impact of problems that may develop if the settlement process is handled differently. In problem-solving indicators, prospective primary school teachers are in the fairly good category. This result means that prospective primary school teachers have begun to solve problems critically by using their mathematical concepts and principles. From the description, the overall critical thinking ability of primary school teacher candidates is fairly good. This is in line with Arifuddin (2020) research that the critical thinking of primary school teacher candidates is good category. They are able to formulate problems, determine facts, and use correct evidence in solving mathematical problems.

Prospective primary school teachers require this critical thinking ability. Critical thinking ability will be able to develop higher-order thinking skills in developing ideas and opinions rationally and relevantly (FitzPatrick \& Schulz, 2015; Simon, 2015; Hwang et al, 2018; Mubarok, Suprapto, \& Adam, 2019; Aisyah et al, 2019; Ghanizadeh, Al-Hoorie \& Jahedizadeh, 2020). The responsibility of primary school teachers is to develop new ideas in finding innovations in the learning process, especially towards the era of society 5.0. This innovation will encourage the development of HOTS for primary school teachers.

Meanwhile, creative thinking ability consists of making decisions, working within limits of competence, trying new things, divergent thinking, and imaginative thinking. This study demonstrates that prospective primary school teachers fall into the "fairly good" category in making decisions. This finding means that teachers have begun to be able to make creative decisions in solving problems. In the indicators of working within limits of competency, prospective primary school teachers are in the fairly good category. This finding indicates that prospective primary school teachers are capable of working within their areas of expertise. They have begun to be able to work beyond their abilities. In other words, primary school teachers are good at solving problems creatively. On the thinking divergently indicator, prospective primary school teachers are in a fairly good category as well. This category indicates that the teachers have been able to find various creative solutions to solve problems. Prospective primary school teachers, on the other hand, are still in the poor category when it comes to trying new things and thinking imaginatively indicators. This category proves that prospective primary school teachers cannot find creative ways outside of the commonly used concepts. Furthermore, prospective primary school teachers are still weak in thinking imaginatively. Both of these abilities are required in the era of society 5.0. 
However, they can be developed through practice. According to this description, primary school teacher candidates have a fairly good creative thinking ability. Creative thinking abilities for prospective primary school teachers are also needed. Creative thinking abilities aim to develop creative thinking patterns in solving problems (Alsowat, 2015; Tanajuya, 2016; Ichsan et al, 2019; Putranta, 2019; Putri \& Hiltrimartin, 2020). Creative thinking ability is a must-have ability in society 5.0. This ability is needed to shape teachers' ability to produce innovations related to society 5.0. These research findings represent fundamental research that can be used to advance other studies. The HOTS of prospective primary school teachers is still in the fairly good category. Therefore, it is necessary to develop HOTS for primary school teacher candidates in the future.

\section{CONCLUSION}

This research concludes that the HOTS ability of prospective primary school teachers is in a good category. Critical thinking abilities include indicators of using concepts, using principles, predicting impacts, and solving problems. They are all in a fairly good category. Besides, creative thinking ability is in a fairly good category with indicators of making decisions, working within the limits of competency, and thinking divergently. Meanwhile, the indicators of trying new things and thinking imaginatively are in the poor category. This study has a contribution to the field of education. It is possible to use the HOTS ability of elementary school teachers as a recommendation for efforts to increase the HOTS ability. This is because elementary school teachers play a critical role in building pupils' fundamental knowledge and abilities. This research can be used as a reference as well as a foundation for designing specific policies and strategies to improve elementary school learning quality.

\section{REFERENCES}

Abdullah, A. H., Mokhtar, M., Abd Halim, N. D., Ali, D. F., Tahir, L. M., \& Kohar, U. H. A. (2016). Mathematics teachers' level of knowledge and practice on the implementation of higher-order thinking skills (HOTS). Eurasia Journal of Mathematics, Science and Technology Education, 13(1), 3-17.

Ahmad, S. S., Ahmad, S., Kenedi, A. K., \& Helsa, Y. (2019, December). Learning Model and Higher-Order Thinking Skill in Advanced Mathematical Study. In 5th International Conference on Education and Technology (ICET 2019). Atlantis Press.

Ahmad, S., Kenedi, A. K., Ariani, Y., \& Sari, I. K. (2019, October). Instrument higher-order thinking skill design in course high-class mathematics in elementary school teacher of the education department. In Journal of Physics: Conference Series (Vol. 1321, No. 2, p. 022129). IOP Publishing. 
Ahmad, S., Prahmana, R. C. I., Kenedi, A. K., Helsa, Y., Arianil, Y., \& Zainil, M. (2017, December). The instruments of higher-order thinking skills. In Journal of Physics: Conference Series (Vol. 943, No. 1, p. 012053). IOP Publishing.

Aisyah, A., Salehuddin, K., Aman, I., Yasin, R. M., \& Mimiko, N. (2019). Eliciting Elements of Higher Order Thinking Skills in the Higher Secondary Examination Question Structure in Japan and Malaysia. In Proceedings of the Regional Conference on Science, Technology and Social Sciences (RCSTSS 2016) (pp. 455-464). Springer, Singapore.

Allamnakhrah, A. (2013). Learning Critical Thinking in Saudi Arabia: Student Perceptions of Secondary Pre-Service Teacher Education Programs. Journal of Education and learning, 2(1), 197-210.

Alsowat, H. (2016). An EFL flipped classroom teaching model: Effects on English language higher-order thinking skills, student engagement, and satisfaction. Journal of Education and Practice, 7(9), 108-121.

Apino, E., \& Retnawati, H. (2018). Creative problem solving for improving students' higherorder thinking skills (HOTS) and characters. In Character Education for 21st Century Global Citizens (pp. 249-256). Routledge.

Arifuddin, A. (2019). Students'critical And Creative Thinking Skills On Mathematics Learning In Madrasah Ibtidaiyah. Auladuna: Jurnal Pendidikan Dasar Islam, 6(1), $38-49$.

Arifuddin, A. (2020). The Analysis of Critical Thinking Skills of Primary School Teacher Candidates in Solving Mathematical Problems. Al Ibtida: Jurnal Pendidikan Guru MI, 7(1), 46-55.

Carayannis, E. G., Draper, J., \& Bhaneja, B. (2020). Towards fusion energy in the Industry 5.0 and Society 5.0 context: Call for a global commission for urgent action on fusion energy. Journal of the Knowledge Economy, 1-14.

Dubas, J. M., \& Toledo, S. A. (2016). Taking higher-order thinking seriously: Using Marzano's taxonomy in the economics classroom. International Review of Economics Education, 21, 12-20.

Eliyasni, R., Kenedi, A. K., \& Sayer, I. M. (2019). Blended Learning and Project-Based Learning: The Method to Improve Students' Higher Order Thinking Skill (HOTS). Jurnal Iqra': Kajian Ilmu Pendidikan, 4(2), 231-248.

Evtodieva, T. E., Chernova, D. V., Ivanova, N. V., \& Wirth, J. (2020). The internet of things: possibilities of application in intelligent supply chain management. Digital transformation of the economy: Challenges, trends, and new opportunities, 395-403.

Fachrunnisa, O., Adhiatma, A., \& Tjahjono, H. K. (2020, July). Spiritual Welfare Creation for Knowledge Workers in Society 5.0: A Conceptual Model. In Conference on Complex, Intelligent, and Software Intensive Systems (pp. 300-306). Springer, Cham.

FitzPatrick, B., \& Schulz, H. (2015). Do curriculum outcomes and assessment activities in science encourage higher-order thinking?. Canadian Journal of Science, Mathematics and Technology Education, 15(2), 136-154.

Fujii, T., Guo, T., \& Kamoshida, A. (2018, August). Consideration of service strategy of Japanese electric manufacturers to realize super-smart society (Society 5.0). In International Conference on Knowledge Management in Organizations (pp. 634645). Springer, Cham. 
Garcia, L. C. (2015). Environmental science issues for higher-order thinking skills (HOTS) development: a case study in the Philippines. In Biology Education and Research in a Changing Planet (pp. 45-54). Springer, Singapore.

Ghanizadeh, A., Al-Hoorie, A. H., \& Jahedizadeh, S. (2020). Higher-order thinking skills in the language classroom: A concise guide. Springer.

Habók, A., \& Nagy, J. (2016). In-service teachers' perceptions of project-based learning. SpringerPlus, 5(1), 1-14.

Hwang, G. J., Lai, C. L., Liang, J. C., Chu, H. C., \& Tsai, C. C. (2018). A long-term experiment to investigate the relationships between high school students' perceptions of mobile learning and peer interaction and higher-order thinking tendencies. Educational Technology Research and Development, 66(1), 75-93.

Ichsan, I. Z., Sigit, D. V., Miarsyah, M., Ali, A., Arif, W. P., \& Prayitno, T. A. (2019). HOTS-AEP: Higher Order Thinking Skills from Elementary to Master Students in Environmental Learning. European Journal of Educational Research, 8(4), 935-942.

Incikabi, L., Tuna, A., \& Biber, A. C. (2013). An analysis of mathematics teacher candidates' critical thinking dispositions and their logical thinking skills. Journal of International Education Research (JIER), 9(3), 257-266.

Lu, K., Pang, F., \& Shadiev, R. (2021). Understanding the mediating effect of learning approach between learning factors and higher-order thinking skills in collaborative inquiry-based learning. Educational Technology Research and Development, 1-18.

Mubarok, H., Suprapto, N., \& Adam, A. S. (2019, February). Using inquiry-based laboratory to improve students' higher-order thinking skills (HOTS). In Journal of Physics: Conference Series (Vol. 1171, No. 1, p. 012040). IOP Publishing.

Polat, L., \& Erkollar, A. (2020, September). Industry 4.0 vs. Society 5.0. In The International Symposium for Production Research (pp. 333-345). Springer, Cham.

Pratama, G. S., \& Retnawati, H. (2018, September). Urgency of higher-order thinking skills (HOTS) content analysis in a mathematics textbook. In Journal of Physics: Conference Series (Vol. 1097, No. 1, p. 012147). IOP Publishing.

Putranta, H. (2019, December). Synthesis of the cognitive aspects' science literacy and higher-order thinking skills (HOTS) in chapter momentum and impulse. In Journal of Physics: Conference Series (Vol. 1397, No. 1, p. 012014). IOP Publishing.

Putri, R. I. I., \& Hiltrimartin, C. (2020, March). Secondary students' higher-order thinking skills in solving PISA-like mathematical tasks. In Journal of Physics: Conference Series (Vol. 1480, No. 1, p. 012034). IOP Publishing.

Saputro, S., Perdana, R., Atmojo, I. R. W., \& Nugraha, D. A. (2020, April). Development of Science Learning Model towards Society 5.0: A Conceptual Model. In Journal of Physics: Conference Series (Vol. 1511, No. 1, p. 012124). IOP Publishing.

Shukla, D., \& Dungsungnoen, A. P. (2016). Student's Perceived Level and Teachers' Teaching Strategies of Higher Order Thinking Skills: A Study on Higher Educational Institutions in Thailand. Journal of Education and Practice, 7(12), 211-219.

Simon, N. (2015). Improving higher-order learning and critical thinking skills using virtual and simulated science laboratory experiments. In New Trends in Networking, Computing, E-learning, Systems Sciences, and Engineering (pp. 187-192). Springer, Cham. 
Somatanaya, A. G., \& Nugraha, D. A. (2018). Pemetaan high order thingking (HOT) matematis siswa sekolah menengah pertama se-kota tasikmalaya. Teorema: Teori dan Riset Matematika, 3(2), 187-194.

Tanujaya, B. (2016). Development of an Instrument to Measure Higher Order Thinking Skills in Senior High School Mathematics Instruction. Journal of Education and Practice, 7(21), 144-148.

Tanujaya, B., Mumu, J., \& Margono, G. (2017). The Relationship between Higher Order Thinking Skills and Academic Performance of Student in Mathematics Instruction. International Education Studies, 10(11), 78-85.

Wan, J., Li, J., Hua, Q., Celesti, A., \& Wang, Z. (2020). Intelligent equipment design assisted by Cognitive Internet of Things and industrial big data. Neural Computing and Applications, 32(9), 4463-4472.

Winkelhaus, S., \& Grosse, E. H. (2020). Logistics 4.0: a systematic review towards a new logistics system. International Journal of Production Research, 58(1), 18-43. 